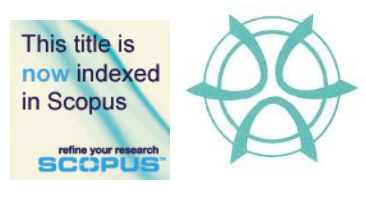

PLANNING MALAYSIA:

Journal of the Malaysian Institute of Planners

VOLUME 17 ISSUE 1 (2019), Page 240 - 249

\title{
ANALYTIC HIERARCHY PROCESS: AN EMPIRICAL VALUATION FOR INTANGIBLE ASSETS
}

\author{
Jerri Falson ${ }^{1}$ \\ Ministry of Finance \\ REPUBLIC OF INDONESIA
}

\begin{abstract}
Intellectual capital or intangible assets has become widely accepted as one of the most important assets of many of the world's largest companies. However, it is often pointed out that conclusion about valuation in intellectual capital shows a significant difference to capture the potential corporate value activities and determine their future earnings. This paper empirically investigates valuation in the intellectual capital by applying the Analytic Hierarchy Process (AHP) by sorting the non-financial value driver for their weight contributions. It uses topfour industrial sectors in Indonesia which are competing in a distinctive sector to find the observable performance differences. Simultaneously, to complete this research, questionnaires were distributed to valuers in the headquarter of Indonesian Directorate General of State Assets Management (DGSAM). AHP model was used to explore the value weights and ranks among those industries. The findings in this paper are focused on investigating the relative value distribution and determining the diverse patterns across industry by highlighting the importance of intellectual capital to create value advantages.
\end{abstract}

Keyword: valuation, AHP, intangible, intellectual capital 
PLANNING MALAYSIA

Journal of the Malaysia Institute of Planners (2019)

\section{INTRODUCTION}

Intellectual capital or intangible assets are recognized as one of the most important assets of many of the world's largest and most powerful companies (Lin $\&$ Tang, 2009). Especially in recognition for the purpose of mergers, acquisitions, and accounting report, right now, it is still difficult to understand the reliability of the value of intellectual capital (Frederick, 2009). Intellectual capital can also cause a direct effect in assessing the firm value that sometimes under-valued. Thus, the ability of an enterprise to gain its competitive advantages and to support them as well is partly determined by its core competencies that are embedded deep within an organization (Stan, Dumitrascu, \& Pele, 2017). The importance and complexity of intangible assets has created a purpose for valuation, for example in financial reporting purposes as well as for the management of state finances.

Ocean Tomo ("Ocean Tomo Releases 2015 Annual Study", 2015) has released its findings from Intangible Asset Market Value Study of the composition of equity market values that reported the components of S\&P market value as illustrated in Figure 1. Following the finding, by looking into the trends portion of company's report in S\&P 500, it is crystal clear that since two-decade ago, more than half of investment has been invested in intangible asset.

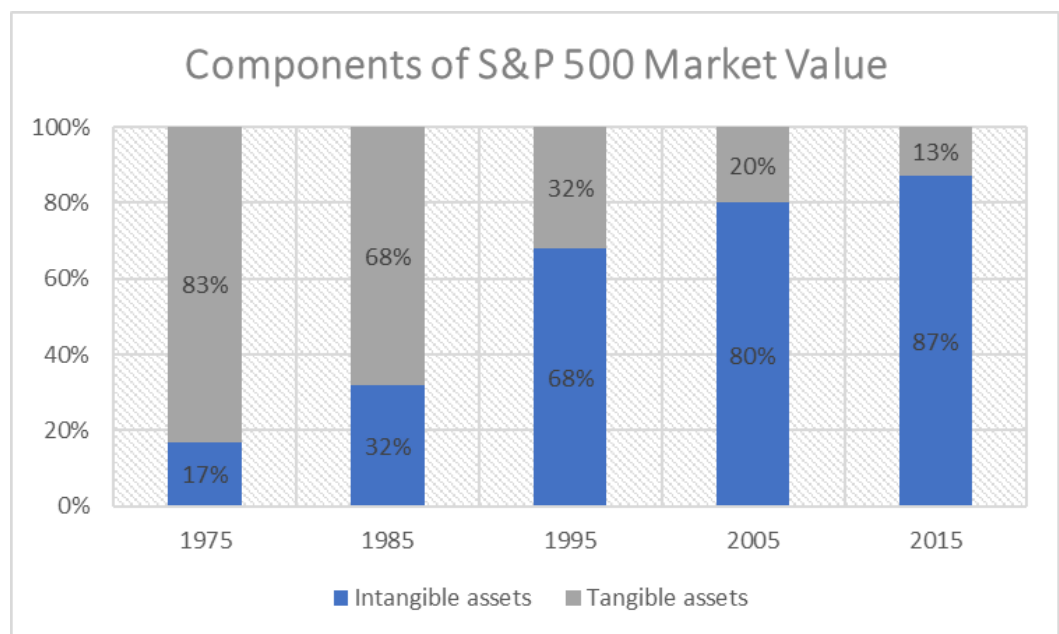

Figure 1: Comparison between investment in tangible and intangible asset Source: Ocean Tomo (2015)

Accordingly, this paper investigates the relative value distribution of a company's intangible assets, which is closely related to the concept and application of "value drivers". Furthermore, the value drivers will significantly determine the level of intangible asset that could be created through an analytic hierarchy (AHP) process. Following Lin and Tang (2009), the AHP method in 
Jerri Falson

Analytic Hierarchy Process: An Empirical Valuation for Intangible Assets

valuation process was set up to sort the non-financial value drivers according to their weighted contributions. Using AHP will help companies to assess appropriately and to avoid bias in measuring the fair value of an entity. In addition, by giving the substantial part of intangible assets to the contribution of total assets in many industries, the top-four industries basically from their volatility and their trading volume in Indonesia Stock Exchange, Indonesia, were used as the object of indicator to professional valuer in DGSAM in order to test the suitability of applications, models, and explore the weight of the value of intangible assets and its evaluation among different industries.

This paper examines the intellectual capital in relation to research on contemporary valuation analysis. The focus is on one of the most 'visible' research subjects: intangible assets. In doing so, this paper explores the 'silences and secrets' of the intellectual practices through which drivers are recognized as a missing problem. This intellectual capital research field is a fertile opportunity to examine the constellation of academic and practical knowledge. This research represents a desire to contribute in business valuation which also has played a central role and important matter of concern in making decision.

\section{RESEARCH BACKGROUND}

\section{Indonesia Stock Exchange}

The presence of capital market or stock exchange in Indonesia began in the era of Dutch East Indies on December 14, 1912, when the Dutch government through the Amsterdam Stock Exchange established a stock exchange association in Jakarta (ISE, 2014). And legally, PT Bursa Efek Indonesia (the Company) was established based on notarial deed No. 27 dated December 4, 1991 as amended by notarial deeds No. 142 dated December 13, 1991 and No. 254 dated December 21, 1991 (ISE, 2014). By stepping up for its growth, compared to regional exchanges, IDX's achievement is promising although not the best (ISE, 2016a) However, the performance of Indonesian capital markets had made encouraging progress until 2016.

Until the end of 2016, the top big-four sectors in IDX were in mining, agriculture, property and financial, which boosted the overall growth of listed company in Indonesia. Based on data from Indonesia Stock Exchange Statistic (ISE, 2016b), the average index rate indicated that four sectors in the Indonesia Stock Exchange 2015-16 were rather stable (Figure 2). Otherwise, the trading volume that indices by the bar from the left axis shows the dynamics of the number in million shares that has been distributed in the past two years.

\section{AHP}

Apparently, AHP is a theory and methodology for relative measurement (Saaty, 1990), which is not kind of an exact measurement of some quantities, but rather 
on the proportions between them (Brunelli, 2015). Formally, to operationalize, in a decision process there are several sets of AHP pillars, which are (i) ratio scales, proportionally and normalized ratio scales (ii) reciprocal paired comparisons (iii) the sensitivity of the principal eigenvector (iv) clustering and using pivots to extend the scale (v) synthesis to create a one-dimensional ratio for representing the overall outcome (vi) rank preservation and reversal, and (vii) integrating group judgments (Lamata, 2006).
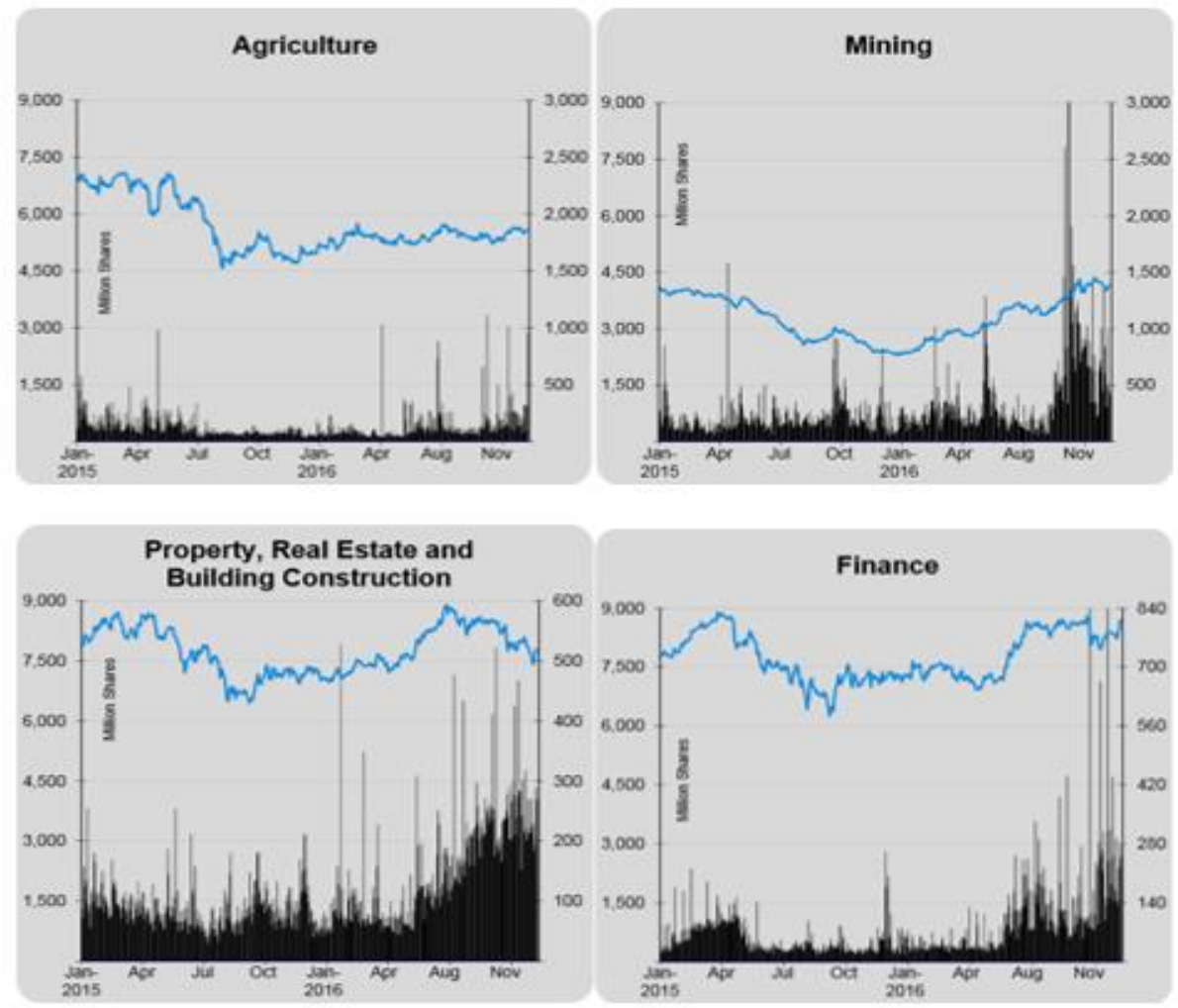

Figure 2: Comparison between 4 big industries in Indonesia (2016) Source: ISE (2016b)

Making decision in AHP stage seems easy, however, to understand the principles behind the AHP and real-world applications have presented a much higher level of complexity while we would note that hierarchies can contain more levels of criteria (Brunelli, 2015). The reason to overcome this problem is to use pairwise comparisons which allows the decision maker to consider two alternatives at a time (Saaty, 1990). Thus, the strategy is that of decomposing the original problem into many smaller subproblems and deal with these latter ones (Brunelli, 2015). Formally, the pairwise comparison is an effective way to 
Jerri Falson

Analytic Hierarchy Process: An Empirical Valuation for Intangible Assets

aggregate the relative weights of decision elements to arrive at a set of ratings for the decision alternatives (Zahedi, 1986).

Saaty (1990) proposed a simple formula for pairwise comparison by using a matrix equation which has positive entries in single row and column, as the origin of his fundamental scale of absolute number (Table 1), with reciprocal property (Figure 3 ). The solution of those multiplication $=\mathrm{nw}$, named the principal right eigenvector which consists of positive entries and is unique to within a multiplicative constant (Saaty, 1990).

Table 1: Level of importance in AHP

\begin{tabular}{|c|c|c|}
\hline $\begin{array}{l}\text { Intensity of } \\
\text { importance }\end{array}$ & Definition & Explanation \\
\hline 1 & Equal importance & Two activities contribute equally to the objective \\
\hline 3 & Moderate importance & $\begin{array}{l}\text { Experience and judgement slightly favor one } \\
\text { activity over another }\end{array}$ \\
\hline 5 & Strong importance & $\begin{array}{l}\text { Experience and judgement strongly favor one } \\
\text { activity over another }\end{array}$ \\
\hline 7 & $\begin{array}{c}\text { Very strong or } \\
\text { demonstrated importance }\end{array}$ & $\begin{array}{l}\text { An activity is favored very strongly over another; } \\
\text { its dominance demonstrated in practice }\end{array}$ \\
\hline 9 & Extreme importance & $\begin{array}{l}\text { The evidence favoring one activity over another is } \\
\text { of the highest possible order of affirmation }\end{array}$ \\
\hline $2,4,6$ and 8 & $\begin{array}{c}\text { Intermediate values } \\
\text { between the two-adjacent } \\
\text { judgement }\end{array}$ & When compromise is needed \\
\hline ource: Saaty $(1$ & & \\
\hline & {$\left[\begin{array}{cc}w 1 / w 1 & \cdots \\
\vdots & \ddots \\
w n / w 1 & \cdots \\
& \begin{array}{r}\text { Figure } \\
\text { Sour }\end{array}\end{array}\right.$} & 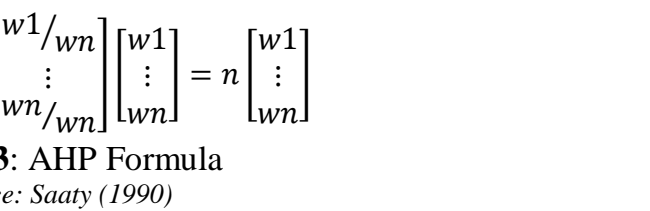 \\
\hline
\end{tabular}

Those results must meet the consistence level of the relative importance of the attributes. Since subjective judgment may present decision biases, its consistency must be checked. It is a common that the pairwise comparison is considered consistent when the consistency index value is less than 0.10 .

\section{Intangible Assets}

Lev (2001) emphasized that intangible is an asset which is claims to future benefits with no physical or financial embodiment, with the term intangibles, knowledge assets and intellectual capital are used interchangeably. Terminology of 'intangible assets', in this research, is obvious from 'intangibles' in the financial report. The value to the company which are long term, and just as typically they cannot be accurately valued until the company is sold, being then converted to and lumped under the title 'goodwill', which is calculated as the 
PLANNING MALAYSIA

Journal of the Malaysia Institute of Planners (2019)

difference between purchase price and book value (Daum, 2003). It focuses on resources that are not material, and highlights the growing importance in the economy and in companies of this hidden wealth (Andriessen, 2004).

\section{Creating the Value Driver}

Corporations sometimes choose not to focus on value creation and, instead, unintentionally make decisions that systematically decrease the long-term value of their businesses (Lin \& Tang, 2009). The definitions of value creation depends on the relative amount of value that is subjectively realized by a target user (or buyer) who is the focus of value creation, whether individual, organization, or society, and that this subjective value realization must at least translate into the user's willingness to exchange a monetary amount for the value received (Lepak, Smith, \&Taylor, 2007). Lepak, Smith and Taylor (2007) also stated two important economic conditions that may be necessary for value creation activities to endure as:

- the monetary amount exchanged must exceed the producer's costs (money, time, effort, joy, and the likes) of creating the value in question, at least for the single point in time when the exchange occurs; and

- the monetary amount that a user will exchange is a function of the perceived performance difference between the new value that is created (from the new focal task, product, or service) and the target user's closest alternative (current task, product, or service).

It is an interesting subject when accounting does not provide an effective information and how to create the value to leverage corporate intellectual capital. Value creation also creates new competitive space for firms and sustainable competitive advantage in business enterprise (Prahalad \& Ramaswamy, 2004). However, in building the value creation, managers should decide which assets are the most important drivers of the company's value-creation system (Lin \& Tang, 2009). For instances, setting up the efficient manufacturing process, innovation through product development, creating a new brand, e-commerce, and easy data interchange from software application.

Theoretically, an asset, whether tangible or intangible, is assessed through its expected future discounted cash flow. This is the basic principle of the discounted cash flow. From such premise, strategies drawn by a company may positively or negatively affect a given company's value. Consistent with this principle, Lev (2001) defined intangible asset as a right for future benefits that do not have a physical or financial body (stocks or debt securities). In order to allow a better understanding of the intangible asset concept, it is necessary to present its classification.

Lin and Tang (2009) stated that it is necessary to differentiate intangible assets from drivers that lead to the formation of their values, which means intangible assets must not be considered as drivers themselves. In other words, 
Jerri Falson

Analytic Hierarchy Process: An Empirical Valuation for Intangible Assets

those non-financial components would be related by the definition of the intangible assets' values. Kalafut and Low (2001) suggested that the critical drivers are innovation, quality, customer relation, management capabilities, alliances, technology, brand value, employee relations, and environmental and community issues. Looking deeply, all of those are non-financial drivers. In understanding the important nature of intangible assets, then the drivers are attributes that may be associated with different types of intangible assets. Meanwhile, the higher or lower intensity in the relative importance of each driver may influence the formation of value for intangible assets (Lin \& Tang 2009).

\section{CONSTRUCTING THE RESEARCH MODEL}

By understanding the category of drivers developed by Kalafut and Low (2001), a quantitative research was conducted. It consisted of four assessing dimension drivers and 11 assessing criteria for probing into the issue regarding the value of weights of intangible assets in mining, agricultural, property and finance industries. The research model was then validated by speakers and practitioners from Directorate General of State Asset Management (DGSAM) Head Office, to ensure that the model constructed fits the needs and is reasonable.

For primary dataset, a questionnaire was developed to help allocating the assessment dimension. The sample of assessment dimension was derived from certified valuer in DGSAM or at least a non-certified valuer but has completed the 200 hours of training in valuation. A total of 102 copies of questionnaires were issued. While 82 copies were valid, all of them recollected with $\mathrm{CI} / \mathrm{CR}$ ratio less than 0.1 were selected to be effective analysing samples.

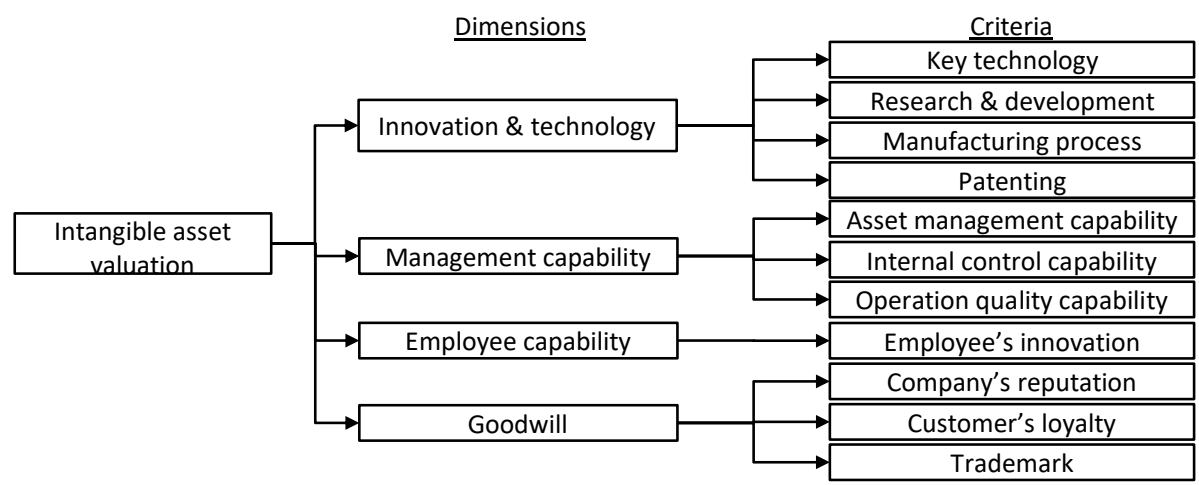

Figure 4: The model of intangible asset evaluation Source: Lin \& Tang (2009)

Therefore, the AHP method was used during the survey, attempting to quantitatively rank the non-financial contributions as shown in Figure 4. The implicit assumption underlying here is that genuine intangible asset values may 
vary between firms, but professional executives within the same industry should have a converged idea regarding the ways in which the intangible assets should be arrayed when they consider comparing the relative importance of the value drivers. Therefore, directly after obtaining the ideal measure of intangible assets surveyed through AHP, other methods can be used by the management in order to assess the way in which the arrangement of the individual company's intangibles is diverged from the so-called ideal structure; this is particularly useful while encountering business mergers and acquisitions since it serves as a helpful reference for business valuation.

\section{RESULTS AND ANALYSES}

Table 2 shows the weights (relative importance) of intangible asset appraising dimensions assigned by the professional executives in DGSAM. 'Technology innovation' has been considered as the most important dimension, which has weights 0.55 for Mining industry and 0.48 for Agricultural industry. In the same way, both of Mining and Agricultural industries have the least weight in 'goodwill' dimension for 0.05 and 0.06. On the other hand, 'management capability' has been reached as the highest dimension which has 0.56 in Property and 0.54 in Finance sector while 'technology innovation' only 0.12 and 0.08 in those sectors.

Table 2: The weights of appraising dimension of intangible assets in different industries

\begin{tabular}{|l|c|c|c|c|}
\hline \multicolumn{1}{|c|}{ Industry category } & $\begin{array}{c}\text { Technology } \\
\text { innovation }\end{array}$ & $\begin{array}{c}\text { Management } \\
\text { capability }\end{array}$ & $\begin{array}{c}\text { Employee } \\
\text { capability }\end{array}$ & Goodwill \\
\hline Mining Sector & 0.55 & 0.28 & 0.12 & 0.05 \\
\hline Agricultural Sector & 0.48 & 0.29 & 0.17 & 0.06 \\
\hline Property & 0.12 & 0.56 & 0.14 & 0.17 \\
\hline Finance & 0.08 & 0.54 & 0.13 & 0.25 \\
\hline
\end{tabular}

Source: This Study

In terms of the criteria, as shown in Table 3, the non-financial driver performance of the Mining industries was modest; the top-three highest score were Key Technology (0.306), R\&D capability (0.195), and Manufacturing process $(0.121)$. Despite the fact that they are operating in distinct domains of activity, the top-three highest drivers in Agriculture sector were the same with the Mining sector, which were R\&D capability $(0.252)$, Key Technology $(0.184)$, and Manufacturing process $(0.114)$. This could be due to the fact that those knowledge-manufacturing industries need to know the importance of research and how to make an efficient process. This source is the crucial factor affecting a company's ability to remain competitive in the marketplace. 
Jerri Falson

Analytic Hierarchy Process: An Empirical Valuation for Intangible Assets

Table 3: The weight of appraising criteria of intangible assets in different industries

\begin{tabular}{l|c|c|c|c}
\hline Appraising criterion & Mining & Agriculture & Property & Finance \\
\hline Innovation and Technology & & & & \\
Key Technology & $0.306(1)$ & $0.184(2)$ & $0.030(10)$ & $0.022(11)$ \\
R \& D capability & $0.195(2)$ & $0.252(1)$ & $0.034(8)$ & $0.034(8)$ \\
Manufacturing process & $0.121(3)$ & $0.114(3)$ & $0.034(9)$ & $0.026(9)$ \\
Patenting & $0.036(9)$ & $0.051(7)$ & $0.024(11)$ & $0.024(10)$ \\
\hline Management Capability & & & & \\
Asset Management capability & $0.062(5)$ & $0.071(6)$ & $0.336(1)$ & $0.288(1)$ \\
Internal Control capability & $0.056(7)$ & $0.048(9)$ & $0.101(4)$ & $0.104(3)$ \\
Operation quality capability & $0.058(6)$ & $0.043(10)$ & $0.122(2)$ & $0.168(2)$ \\
\hline Employee Capability & & & & \\
Employee's innovation & $0.063(4)$ & $0.074(5)$ & $0.059(7)$ & $0.076(7)$ \\
\hline Goodwill & & & & \\
Company's reputation & $0.036(8)$ & $0.077(4)$ & $0.112(3)$ & $0.099(4)$ \\
Customers's loyalty & $0.034(10)$ & $0.051(8)$ & $0.080(5)$ & $0.082(5)$ \\
Trademark & $0.033(11)$ & $0.035(11)$ & $0.068(6)$ & $0.077(6)$ \\
\hline
\end{tabular}

Source: This Study

For Property sector and Finance industry, the highest was Asset Management capability, with score of 0.336 for Property and 0.288 in Finance. This is followed by Operation quality capability, which scored 0.122 for Property sector and 0.168 Finance $(0.122$ and 0.168$)$. The distribution highlights the characteristics of those industries at their level of risk-associated with the degree of investment. Therefore, if the firms were responsible for improving asset management capability and operation quality, their action will be reflected in how they develop their relationship with their investors to capture the competitive advantage in those sectors.

\section{CONCLUSION}

In the context of this paper, we have seen how intangible assets correspond to corporate value creation and represent the source of non-financial competitive advantage. Intangible asset in its economic aspects is embedded in the problematic dynamics of the market economy and is more likely to help businesses avoid bias due to mainly relying on financial statements when measuring an entity's value.

By referring to the significant proportion of intangible assets, this research provides different platforms within four industries in Indonesia, as well as the value weights and their evaluation among different high-dynamic industries. The result indicates the importance of development in intellectual capital in several sectors of industries. By using AHP, managers can have a complete image on what is happening inside the selected sector of the firms. On the other hand, they can identify some potential threats and opportunities, they can monitor changes and they can develop future strategies (compared with their competitors and business partners) (Leon, 2016). 
PLANNING MALAYSIA

Journal of the Malaysia Institute of Planners (2019)

\section{REFERENCES}

Andriessen, D. (2004). Making sense of intellectual capital: Designing a method for the valuation of intangibles. Oxford: Elsevier.

Brunelli, M. (2015). Introduction to the analytic hierarchy process. Finland: Springer.

Daum, J.H. (2003). Intangibles assets and value creation. Chichester: Wiley.

Frederick, W. (2009). Recent developments in intellectual capital reporting and their policy implications. OECD Education Working Papers, No. 17. Paris: OECD Publishing.

Indonesia Stock Exchange [ISE] (2014). 2014 Annual Report. Retrieved from http://www.idx.co.id/id-id/beranda/tentangbei/laporantahunan.aspx.

Indonesia Stock Exchange [ISE] (2016a). IDX Fact Book 2016. Retrieved from http://www.idx.co.id/Portals/0/StaticData/Publication/FactBook/FileDownload/ 20161025_FB-2016.pdf.

Indonesia Stock Exchange [ISE] (2016b). IDX Statistics 2016. Retrieved from http://www.idx.co.id/id-id/beranda/publikasi/statistik.aspx.

Kalafut, P. C., \& Low, J. (2001). The value creation index: Quantifying intangible value. Strategy \& Leadership, 29(5), 9-15.

Lamata, M. T. (2006). An alternative solution to the analytic hierarchy process. International Journal of Intelligent Systems, 21, 425-441.

Lepak, D. P., Smith, K. G., \& Taylor, M. S. (2007). Value creation and value capture: A multilevel perspective. Academy of Management Review, 32(1), 180-194.

Leon, R. D. (2016). Intellectual capital - Source of competitiveness. International Journal Learning and Intellectual Capital, 13, 149-166.

Lev, B. (2001). Intangibles: Management, measurement and reporting. Washington: Brookings.

Lin, G., \& Tang, J. (2009). Appraising intangible assets from the viewpoint of value drivers. Journal of Business Ethics, 88(4), 679-689.

Ocean Tomo. (2015). Ocean Tomo releases 2015 annual study of intangible asset market value. $\quad$ Retrieved February 2, 2018, from http://www.oceantomo.com/blog/2015/03-05-ocean-tomo-2015-intangibleasset-market-value/

Prahalad, C. K., \& Ramaswamy, V. (2004). Co-creation experiences: The next practice in value creation. Journal of Interactive Marketing, 18(3), 5-14

Saaty, T. (1990). How to make a decision: The analytic hierarchy process. European Journal of Operational Research, 48, 9-26.

Stan, S., Dumitrascu, D., \& Pele, A. (2017). Recognizing and valuating intangible resources - Major difficulties in organisational management. Management of Sustainable Development Sibiu, 9(1). 35-38.

Zahedi, F. (1986). The analytic hierarchy process: A survey of the method and its applications. Interfaces, 16(4), 96-108.

Received: $28^{\text {th }}$ October 2018. Accepted: $1^{\text {st }}$ March 2019 